\title{
The Manhaj of Figh-Ul-Hadith by Shaykh Hurr Ameli on the basis of Wasael ush-Shia
}

\author{
Hosein Rahmani Tirkalai \\ Department of Theology, Payame Noor University, PO BOX 19395 - 3697, Tehran, IRAN
}

Corresponding Author: Rahmanitirkalai1391@yahoo.com

Keywords: Manhaj, Shaykh Hurr Ameli, Wasael ush-Shia, hadith, Fiqh-ul-Hadith.

\begin{abstract}
Undoubtedly, the most important part of a book replete with hadiths is related to the texts of hadiths. Today, such studies about hadith are called Fiqh-al-Hadith which these studies are represented only for searching the exact meaning and concept in the texts for this, Scholars attempt to study terms of Hadith and narrative, and also they strived to compare these narratives with Quran, history, logical particles, and etc by which the final concept of narratives would be found. This fact is also true for the definitions represented in narrative books. It has to be noticed that as shown in dignitaries sayings and topics, Shaykh Hurr Ameli was interested in declarative inclinations and he knew all the narratives in the four books and also all the resources in Wasael ush-Shia authentic and accurate. This outlook was influential on the way he behaves with narratives. In $27^{\text {th }}$ volume of Wasael ush-Shia about "Inadmissibility of theoretical precepts of the phenomena of the Quran" and after mentioning a narration by Amir al-Momenin alayhis salam, believes that ayatul ahkam is from the cases which only fourteen infallible could get recognition of it. The present paper is such a philosophical theological Inquiry by which an observation about the Manhaj of Ahl Ul Hadith by Shaykh Hurr Ameli on the basis of Wasael ush-Shia has been provided.
\end{abstract}

\section{INTRODUCTION}

After Quran, the second source for getting recognition of precepts and Islamic Beliefs was the Prophet and prophetic traditions and fourteen infallible's hadiths. In several verses of Quran, proof and validity of self traditions and also prophetic narrations have been mentioned. According to the verses of Quran, people are obliged to obey prophet as well as obeying God. In the other side, God says about prophet Muhammad: Muhammad is a true prophet which he comes to conduct people. He is believed by Muslims as a messenger and prophet of God. Muhammad is almost universally considered by Muslims as the last prophet sent by God for mankind. Evidences show prophet Muhammad's emphasis Qoutes about hadith. In addition, the hadith collections are accounts of the verbal and physical tradisions of Muhammad dating back to several generation after his death. For instance, prophet Muhammad has focused on quotes about hadith as a common tradition among Muslims in a narration. The narration is brought about as following:

"prophet: God have mercy on my successor, in this case a question was asked as: who are your successors? He gave response as: the ones come after me and narrate my hadiths and also teach them to people are my successors."

One of the methods of prophet Muhammad was to make attendants obliged to listen to his narration in the end of his saying and sermons but about codifying hadith in prophet Muhammad's time, there are some evidence showing the fact that are not only prophet Muhammad was not opposed to hadith, but also he gave advice to his companions to write his narrations.[4] .prophet Muhammad said :do not write anything about me except from Quran and if you wrote anything except from Quran, abolish it. It has to be stated that in this relation, all the narratives are appeared with corruption which accepting them is impossible. According to evidences provided in this base, Omar was so strict about narrating hadiths rather than Abobaker, and this was in a way that the put some of his companions under pressure and did not let them exit from madinah . in the other side, 
Omar invited his workers to put attention on Quran and avoid from narrating Hadith. He also attempted to abolish all the narratives which were accessible for him. In this relation the most important resources to get recognitions of hadith and narrations are mentioned as glossaries of the books written by Sheik Abu Jafar Toosi and Rijal Al-Najashi. Also, in first letters of Boharol Anvar Hadiths, more than 120 principles about hadiths are represented. Most of these principles are abolished by passage of time and only 16 narrative principles for Shia have been remained and it is printed by the title of "principle

\section{MAIN BOY}

Collections are called to the books in which hadith collection with jurisprudential chapters are provided like the six correct books of traditions, fourteen books of Shia'. And also hadith collections including vafi, Wasael Ush-Shia' bohra. also, in casewhile the hadith collections are alphabetic order, an instance could be mentioned here: Ibn al-Asir Collection.

According o the point that no hadith collection in shia in adjusted in alphabetic order, thus the definitions as "Collection are called to the books in which hadith collection with jurisprudential chapters are provided " could come sufficient in this base, Hence, the common point in all hadith collections for shia involving precedent and antecedent hadiths is the fact that jurisprudential chapters have to be included in hadith collections and they have to be adjusted base on jurisprudential chapters. Acctually, there is no difference in the capters whith represetations of beliefs and interpretation like bohra and kkafi , or the capters may not be included of these like edifications and a chapter without jurisprudence.Ibn al-asir is one of the most outstanding traditionists of shi'ie islam.He earned the title of Al shaikh Al Sadoq un account of his great learning and his reputataion for truthfulness. It is a title which he also shares with his father. Abu jafar Muhammad ibn ali ibn babawaih al-Qummi was the leading traditionist of his time $\left(4^{\text {th }}\right.$ century a.h). his birthday is not specified, but people believe that 306 a.h. was his birthday. Father of shaikh SadoQ was from the outstanding Shia' traditionist and as Rejal al-najashi mentioned, ibn 'ali-ibn babawaih is a traditionist in Qom seminary at that time. Imam zaman as brought about a statement about ibn 'ali ibn babwaih and introduced him as "shaikh, truthfull and jurisprudent ",these characteristics show his dignity.[1]

Shaikh sadooq after gaining knowledge from his father and after death of his father attended in Muhammad ibn hasan ahmad ibn valid assembly in 329 A.H. and roughly for 15 years, gained knowledge from his teachings.[2] To respect his professor, he preferred his professor's attitude rather than his father's attitude. Shaikh sadooq moreover gaining knowledge from Muhammad ibn hasan ahmad ibn valid and his father, gained knowledge from Muhammad ibn Ali Majiloyeh, Muhammad ibn moosa ibn al-mutawakkil,ahmad ibn Muhammad ibn yahya al-attar. Shaikh aboo jafar Toosi passed away in 460A.H. . in najaf, an according to his will, he was boried in his home. Two personalities as al shaikh al mofid and seyyed morteza are well-known as the professors of shaikh abo jafar toosi, and actually these personalities are mentioned as the Shiite religious elements. Infinite knowledge and the rathionalism attitude of these two personalities were obvious for every one searching for truth. Undoubtedly, shaikh abo jafar toosi knew his comprehensive knowledge the result of being educated and treated with the effort of his well-known professors, al shaikh al mofid and seyyed morteza. Sheikh toosi attended in Al sheikh Al mofid sessions for five years up to his death, and in 413 A.H., he was his attendant, but, after death of Al shaikh Al mofid, shaikh toosi attended in seyyed mortza sessions and up to end of Seyyed Morteza's life, he continuously attended in his sessions. Sheykh Toosi's hadith collection is comprehensive and his academic issues are unique comparing to other issues. Rijal Al-najashi mentioned 23 books of Sheik Toosi, whereas Sheik Toosi mentioned 41 books of himself, and probably some of his works could be provided after compiling lists, and codifying memoir. Moreover Clairvoyance and edification books, in terms of verbal issues sheikh has provided Talkhis AI-Shafi, AI-Mufsih and AI-Ghaiba, and in terms of interpretation of a book, Al-Tibyan fi Tafsir al-Qur'an by sheikh toosi 
has been provided, and also in terms of jurisprudence, the books Al-Nihaya, AI-Mabsoot, Al-Khilaf were provided and in terms of principles, AI- "Udda book and in terms of dignitaries, AI-Fihrist, Ikhtiyar Marifat al-Rijal. Muharnmad bin al-hassan b. Ali b. al-husayn al-Amili al-Mashghari, commonly known as AI-hurr AI-Amili was born in a village of Mashghar located in Amil mountains of southern Lebanon (1104 A.H.) and he passed way at the age of 71 years old buried in Mashhad city. Actually, AI-hurr AI-,Amili was a muhaddith and a prominent Twelver Shi'a scholar. $\mathrm{He}$ is best known for his comprehensive hadith compilation known as Wasael ush-Shia and as the second of the "Three Great Muhammads" in later Shi'a Islamic history. [8]His early education started with a family of teachers as his father, uncle, grandmother, and his Uncle Sheikh Zein Din Muhammad ibn Hasan. Hence, Sheikh gained most of his knowledge from the people who were in surrounding him. Sheikh hurr in his travel to Isfahan got permission from Allameh Majlesi, and bilaterally Allameh Majlesi got permission from Sheikh hlurr as well. Sheikh hurr had residency in his territory for 40 years. Then, for the purpose of going on a pilgrimage, he went to Iraq and then he travelled to Mashhad (1703, A.H.). As he said, he got interested to stay in Mashhad for taking residency in this city. In Mashhad, he was only continued to compile and teach by which a large number of Shiite scholars gained knowledge by attending in his sessions. After a while post his activities in this relation, he became well-known with qazi al-qozat and Sheykh ol Islam. Sheikh hurr has" 24 volumes of books, and the most important books of him moreover Wasael ush-Shia are al-Jawaher al-saniya fi al-hadith al-qudsiya, Isbat al-Hudat bin al-Nosus wa al-Mujizat, Fawaid alToosiya. [5][4]

\subsection{Sheikh hurr}

Sheikh hurr was not inherited to purity, but his mother was a great symbol of purity which she was also a scholar at that time. Seyed Shahabodin Marashi in saj- Al Balabel has written about mother of Sheikh hurr as "mother of Sheikh hurr is daughter of Allameh Sheikh Abdul Islam who is a scholar". Sheikh hurr after 40 years residency in his hometown decided to travel to Iraq to go on a pilgrimage. His tendency to prophet Muhammad and his ancestries caused him to take his residency in Mashhad in which he continued to teach, compile and codify the hadiths of prophet Muhammad and his ancestries. Eventually, after 31 years residency in Mashhad, Al- Amili died in Mashhad on the 21st of Ramadan $1104 \mathrm{AH} / 26$ May $1693 \mathrm{CE}$ and he was buried there. He was succeeded by his brother Ahmad (d. 1120/1708-9) as shaykh al- Islam in Mashhad.

Allameh Tabatabaei (the writer of Tafsir al-Mizan), says about Wasael ush-Shia that: [6][7].

Wasael ush-Shia is collection of jurisprudent issues which Shia jurisprudents have used it and referred to it for using it for the purpose of narration as well. Great dignities have focused on mimicking from Sheikh hurr which Sheikh hurr's hadith collection has mentioned authentic for using, and in this relation the writer of ghavanin, says, do you know anyone except from Sheikh hurr whose works be authentic, so it has been recommended to mimic his sayings and works which mimicking from others is not appropriate and no one has to refer to others' vote or opinion. The narrations in book "Wasael ush-Shia" have represented in distinctive chapters as religious rules in jurisprudent books in two books as Taharat and Diat. It has been attempted to represent a distinctive chapter for each issue and this could be the reason for an easy access to narrations of books by which referee could find the necessary narrations. Moreover, newer issues based on the content of narrations with a pertinent order could be represented.[6]

\section{DISCUSSION AND RESULTS}

Hadith collection is an issue in jurisprudence and it is useful to get recognition of meaning and concept of hadith which Sheikh has used this issue a lot which in case of denomination to chapters, a meaning was chosen and in the other hand, in some cases general descriptions about hadiths in a chapter were provided, refer to following for this:

Sheikh selected a chapter in the book Al-lihad as lahad Nafs chapter and after finishing this chapter, he got into a conclusion that: wisdom is the saying with many concepts which it could be 
learnt by searching for it, and exactly in hadiths, the main struggle is over meaning for this, person's understanding and perception to distinct between good and evil, and getting recognition of the reasons for affairs and decide what to do and also decide to do good affairs between good and evil. In cases which there are no opponent against hadith, Sheikh mentioned hadiths essential in people's life. hadiths as sayings or acts or tacits ascribed either validly or invalidly to Prophet Muhammad, are obligatory to be narrated by successors of Prophet Muhammad. Sheikh has mentioned the role of hadith essential in all stages of life particularly in death time to remember them. hadith are regarded by traditional Islamic schools of jurisprudence as important tools for understanding the Quran and in matters of jurisprudence. Hadith were evaluated and gathered in large collection from Prophet Muhammad's age. The largest Denominations of Islam rely upon different sets of hadith collections. Different traditions within each denomination, and different scholars within each tradition, may differ as to which hadith should be included in which category. Sometimes Sheikh knows issuing various precepts generated of various issues, for instance the issues include ablution, ceremonial washing, and etc. as known, for performing your ablution, there is no need to wet your ears in ablution, but there is very essential to wet your ears in ceremonial washing, in this relation, Sheikh Durr has represented his opinions. Shahid Sani has mentioned "knowledge of hadith" as a knowledge by which it is discussed about text of hadith, accurate ways for narrating hadith and getting recognition of hadith. Sheikh Bahaei in his book AI- Waj iz has described knowledge of hadith as the knowledge gained from foreign studies by which a comprehensive concept for it could be represented. In this type of knowledge, a collection of hadith has been provided and the issues and discussions about this knowledge have been provided to prove the hadiths. In this relation, Shahid Sani has narrated that the ultimate purpose is getting recognition of news for a better act. After Prophet Muhammad and annihilation of evidences, successors represented a new definition for hadith. Shahid Sani as a traditionist, has represented a concept for hadith as following: "Any Hadith narrated has to be relevant with fourteen infallible's hadiths". Some know this term and concept relevant with Allameh Helli's sayings, whereas other attribute it to Ahmad ibn Tawoos, professor of Allameh Helli." A major problem seen in hadith collections is that hadiths are so long and they are not provided in a summary to give the reader a view. In this relation, it has been attempted to provide a concise text in hadith collection. Hence, Sheikh hurr paid a particular attneiton on this issue and he attempted to give a brief description using various methods, for this refer to following:

-Using the prepositions: In narrating hadiths, quotes have been used which hadiths got popular among people with distributing them.

-Suspension of hadiths: it has been suggested that the original prohibition against Hadith led to a age in which the Quran was able to stand up to critical thinking and questioning; They assumed that the increased reliance on Hadith, which was allegedly illogical and required the suspension of disbelief, led to the eventual downfall of scholastic pursuits in the religion. In this relation, it has been stated that tradition, rather than the Quran, has formed both law and religion for the Moslems. Today, a book was written in defense of the Hadith stating "Anyone who denies the role of Abu Hurayra denies half of the canonical law, for half of the hadiths on which judgments were based had their origin in Abu Hurayra".

-Removing hadiths: in case of repetitive hadiths, Sheikh is obliged to remove them.

Here, Sheikh hurr believes that, however, hypocrisy is taboo in saying your prayers and this fact is brought about in narrations of scholars, only tiredness and fruitlessness in human's life would be achieved. This is a natural fact in human life that sometimes humans are intended to dissimulate in saying their prayers. Signs of hypocrisy are generally seen in humans' life. 


\section{CONCLUSION}

Wasa'il al-Shia' is a reputable book of hadith in Shia Islam, compiled in the ,17th century by Shaikh al-Hur al-Aamili. It is a 20 -volume collection, meant to include all authentic Hadith from the available Shia hadith books, checking their authenticity on the strict principles of Ilm-ur- Rajjal. The author himself started writing commentary Tahreer Wasael ush-Shia of the book, and one volume was publicized. The narrations provided in this book are incomplete which authentic jurisprudent narrations are not mentioned in it, through this Noori was obliged to compile a book to complete the book "Wasael ush-Shia" which as known, the number of narrations in this book is same as the number of narrations provided in the book "Wasael ush-Shia". This shows that Shaikh al-Hur al-Aamili did not pay attention on those narrations or may be the books involved of narrations were not accessible for him or he might be distrusted on those narrations. Sheikh Noori was the first one who paid attention to these points which it could be inferred from him that he referred to this book to gain information to collect hadith. Shaikh al-Hur al-Aamili was an erudite who compiled the book "Wasael ush-Shia" which this book has been introduced as the most comprehensive book among Shi'ah and everyone one interested in knowledge of hadith could refer to this book to get a vast knowledge. a vast but concise compilation and classification of Hadith based on the Four Books (al-Kafi, Man La Yahduruhu al-Faqih, al-Taththib, al- Istibrar) as well as on many later sources. It took 18 years to compose. It is a 20 -volume collection, meant to include all 'authentic' Hadith from the available Shia hadith books, checking their authenticity on the strict principles of I1m-ur-Rajjal.

\section{References}

[1] Ibn Babawaih al-Qummi, Ja'far Muhammad ibn 'Ali, "Meanings of News", corrected by Aliakbar Qafari, Beyrouth, Lebenon, academic magazines institute

[2] lbn al-Asir, Ali ibn Muhammad abol hasan, "Lion Forest to learn companions and Complete History",Beyrouth, Lebenon, Daralhayat arras alarbi, corrected by Adel Ahmad alrfaei

[3] Kulayni, Muhammad Ya'qub, 1994, "Kafi", Tehran, Islamic research institute

[4] Majlesi, Muhammad Baqer, 1979" Rosato mutaqin", compiled by Mosavi Kermani, Qom, Islamic culture foundation

[5] Majlesi, Muhammad Taqi, 1992_1995, "effluents of Sahebgharani", Qom, Ismaeilian institute

[6] Shaikh al-Hur al-Aamili2003 "Wasael ush-Shia", Beyrouth, Lebenon, Daralhayat atras institute

[7] Shaikh al-Hur al-Aamili, 2003 "Guiding People", Mashhad, Islamic Research, Baqdad, Iraq, volume, AI-Andalus

[8]Toosi, Muhammad ibn hasan Abo Jafar, "Foresight", compiled by Barzegar Bafrooei, Qom,Ansarian 